\title{
Study on the Treatment of Acid Mine Wastewater by Coal Fly Ash
}

\author{
Xu Jianping ${ }^{1}$, Wan Haitao ${ }^{2}$ \\ College of Biological and Chemical Engineering \\ Anhui Polytechnic University, Wuhu 241000, China \\ E-mail: 2926258299@qq.com
}

\begin{abstract}
This paper studied the feasibility of treating the acid mine drainage (AMD) by using a process of permeable reactive barrier (PRB), in which coal fly ash(CFA) was used as the reaction medium. The adjustment of $\mathrm{pH}$ and the removal of $\mathrm{COD}$, sulfate and three kinds of heavy metal ions $\left(\mathrm{Cd}^{2+}, \mathrm{Cu}^{2+}\right.$, $\mathrm{Zn}^{2+}$ ) were illustrated. The results showed that the coal fly ash was effective in treating AMD, and the highest removal rates for COD and sulfate could be obtained in $12 \mathrm{~h}$ with $53.4 \%$ and60.4\%, respectively; the maximum removal efficiencies of $\mathrm{Cd}^{2+}, \mathrm{Cu}^{2+}$ and $\mathrm{Zn}^{2+}$ were $42.9 \%, 74.8 \%$ and $26.7 \%$; Besides, in this work, the modification of CFA was conducted by using an acid modification method. In comparison to the original CFA, the modified coal fly ash presented not too bad and displayed a better treatment effect toward the acid mine wastewater. MCFA have higher removal rate of heavy metal ions $\left(\mathrm{Cd}^{2+}, \mathrm{Cu}^{2+}\right.$ and $\left.\mathrm{Zn}^{2+}\right)$, the removal rate of $\mathrm{Cu}^{2+}$ even reached $91.85 \%$.
\end{abstract}

Keywords-AMD; permeable reactive barrier; coal fly ash; modified; treatment effect

\section{INTRODUCTION}

Acid mine drainage (AMD) is an unavoidable byproduct of the mining and mineral industry, especially as far as the oxidation of sulphate minerals is concerned. It typically contain high concentrations of dissolved heavy metals and sulphate, and can have $\mathrm{pH}$ values as low as 2[1]. These conditions may prohibit discharge of untreated acid mine waters into public streams, as they have a detrimental effect on aquatic plant and fish life. Similarly, ground water pollution caused by the drainage of acid mine water is an equally serious problem. Permeable reactive barrier (PRB) are a sustainable technology that can operate over a long time scale with low maintenance [2]. It use the natural hydraulic gradient of the groundwater plume to move the contaminants through the reactive zone giving it an advantage over traditional pump-and-treat technologies by being more cost effective and lower maintenance in the long-term[3]. PRB technology has been successful in remediating a variety of groundwater contaminants including heavy metals [4], organics [5] and radio nuclides. Most PRBs have been installed on industrial, mining and agricultural sites around the world [3-5]. A variety of reactive materials and sorbents, which can be used separately or in combination depending on the groundwater contamination, have been successful in remediating contaminated groundwater in PRBs. These materials, such as $\mathrm{Fe}^{0}$-filings, peat [3], limestone [5], granular activated carbon [6,7] and zeolite [4], are easily available and some are fairly inexpensive. Over the past decade, much work has been done on improving site characterization techniques, developing reactive materials/sorbents, and the installation and design of PRBs.

Coal fly ash is the waste product of coal-burning power plants. Worldwide generation of coal fly ash is about 500 million tons per year [8], which may cause serious environmental problems. In recent years, coal fly ash has been used as cement additive, structural filler, and for road base stabilization [9-11]. Some researchers tested the utilization of coal fly ash as adsorbent to remove heavy metals from wastewater [8, 12-14]. Because of insufficient adsorption capacity, coal fly ash was often modified by soaking in acid or alkaline solution. The chemically modified coal fly ash generally showed larger specific surface area and higher pore volume with low energy consumption, especially when soaked in acid solution [15-17]. In view of the above situation, this paper studied the performance of coal fly ash as the filler of PRB to treat acid mine wastewater, and at the same time, coal fly ash were modified by acid method, and examined the treatment effect of modified coal fly ash (MCFA). It provide a theoretical basis for the treatment of acid mine wastewater by use of CFA as the filler of PRB and made a contribution to resource conservation.

\section{EXPERIMENTAL}

\section{A. Materials}

Simulated acid mine drainage was used in this study. The simulated mine drainage was formulated based on the analysis of mine water samples collected from the field in Anhui province. It was prepared by dissolving the following salts in deionized water: $\mathrm{K}_{2} \mathrm{HPO}_{4}, \mathrm{NH} 4 \mathrm{Cl}, \mathrm{Na}_{2} \mathrm{SO}_{4}$, $\mathrm{CaCl}_{2} \cdot 2 \mathrm{H}_{2} \mathrm{O}, \mathrm{MgSO}_{4} \cdot 7 \mathrm{H}_{2} \mathrm{O}, \mathrm{Fe}\left(\mathrm{NH}_{4}\right)_{2}\left(\mathrm{SO}_{4}\right)_{2} \cdot 6 \mathrm{H}_{2} \mathrm{O}$ and $70 \%$ sodium lactate solution. And then different concentrations of heavy metal ions were added, and the $\mathrm{pH}$ of the simulated AMD was adjusted to 4 using hydrochloric acid. All the chemicals used for the simulated mine water solution were analytical grade. The simulated mine water was analyzed to confirm the exact concentrations. The properties of the simulated acid mine drainage were summarized in Table 1.

The PRB reactor used in the experiment was an organic glass column cylinder designed by myself, its diameter is $6 \mathrm{~cm}, 60 \mathrm{~cm}$ high, water inlet from $5 \mathrm{~cm}$ at the bottom of the reactor, outlet from $6 \mathrm{~cm}$ at the top of the reactor. 
TABLE 1 PROPERTIES OF SimUlated ACID Mine WATER

\begin{tabular}{cc}
\hline index & concentration $(\mathrm{mg} / \mathrm{l})$ \\
\hline $\mathrm{COD}$ & 3004 \\
$\mathrm{SO}_{4}{ }^{2-}$ & 2704 \\
$\mathrm{Cd}^{2+}$ & 7.05 \\
$\mathrm{Cu}^{2+}$ & 2.26 \\
$\mathrm{Zn}^{2+}$ & 10.01 \\
\hline
\end{tabular}

Coal fly ash used in the study was taken from the Thermal Power Station in Wuhu, China, which was residue of anthracite combustion using a pulverized coal fired furnace with an exit gas temperature of $1020^{\circ} \mathrm{C}$. The coal fly ash was oven-dried at $105^{\circ} \mathrm{C}$ for $4 \mathrm{~h}$ and sieved with 100 meshes before use. Chemical composition of the raw coal fly ash (RCFA) was shown in Table 2.

TABLE 2 CHEMICAL COMPOSITION OF THE RAW COAL Fly ASH

\begin{tabular}{cc}
\hline Constituent & Content\% \\
\hline $\mathrm{SiO}_{2}$ & 54.83 \\
$\mathrm{Al}_{2} \mathrm{O}_{3}$ & 28.79 \\
$\mathrm{Fe}_{2} \mathrm{O}_{3}$ & 3.77 \\
$\mathrm{~K}_{2} \mathrm{O}$ & 4.94 \\
$\mathrm{SO}_{3}$ & 1.23 \\
$\mathrm{CaO}$ & 1.22 \\
$\mathrm{MgO}$ & 0.92 \\
Others & 3.03 \\
\hline
\end{tabular}

\section{B. Instrument and Reagent}

Experimental apparatus: UV1901 double beam UVvisible spectrophotometer; WFX-110 flame atomic absorption spectrophotometer; BN2823 electronic scales; PHSJ-3f laboratory $\mathrm{pH}$ meter; high speed tabletop centrifuge; electric drum wind drying oven etc.

\section{Experimental Method and Steps}

1) The preparation method of modified coal fly ash: The dried coal fly ash was soaked in a mixture of sulfuric acid and hydrochloric acid solution at room temperature. During coal fly ash soaking, the mixture was stirred with a speed of $30 \mathrm{rpm}$ for $2 \mathrm{~h}$. After filtration of the mixture, the treated coal fly ash was dried at $105^{\circ} \mathrm{C}$ to a constant weight, milled and sieved with 100 meshes. The modified coal fly ash (MCFA) was obtained.

2) Experimental steps: $50 \mathrm{~cm}$ high coal fly ash was dosed into the PRB reactor, and the AMD was fed by a peristaltic pump at a flow of $1.15 \mathrm{~mL} / \mathrm{min}(5 \mathrm{r} / \mathrm{min})$. The sample was centrifuged from the outlet in a certain time and items including $\mathrm{pH}, \mathrm{COD}$, sulfate and heavy metal ions were measured.

3) Analysis method: Heavy metal ion content by atomic absorption spectrophotometry; $\mathrm{PH}$ by the determination of $\mathrm{pH}$ meter; Determination of COD using the standard potassium dichromate titration method; $\mathrm{SO}_{4}{ }^{2-}$ content using barium chromate spectrophotometry.

\section{EXPERIMENTAL RESULTS AND DISCUSSION}

\section{A. Effect of pH Adjustment for AMD}

From Figure 1, it is clear that CFA has a good effect to adjust the $\mathrm{pH}$ of AMD and can sustained for a long time, it can still adjust $\mathrm{pH}$ from 4.0 to 6.0 when the reaction time was $200 \mathrm{~h}$, which could provide a good acid and alkali environment for the subsequent biological treatment. As the MCFA was modified by the way of chemical acid modification, the positive charge on the surface of CFA was increased compared to the original one, and thus the $\mathrm{pH}$ adjustment was not satisfactory, the initial adjustment effect was not obvious, when the reaction time was $48 \mathrm{~h}$ there was almost no adjustment effect.

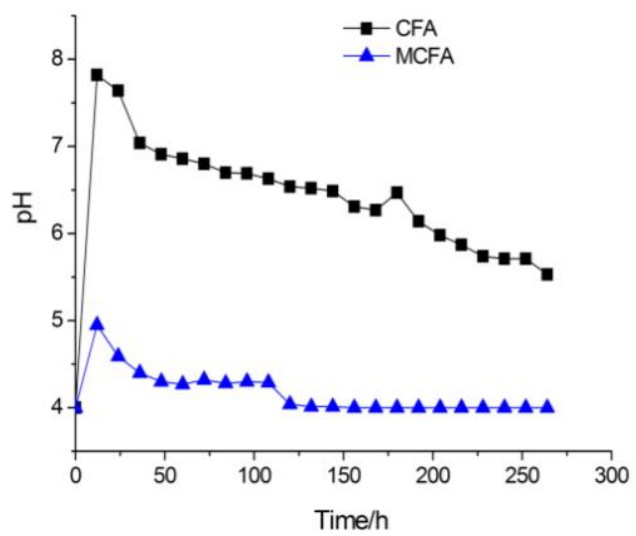

Figure 1. Effect of $\mathrm{pH}$ adjustment

\section{B. Treatment Effect of $C O D$}

As can be seen from Figure 2, the initial COD concentration was about $3000 \mathrm{mg} / \mathrm{L}$, the removal rate of CFA about COD reached the highest of $53.4 \%$ when the reaction was $12 \mathrm{~h}$ and decreased as time increased, when the reaction time was $200 \mathrm{~h}$ the COD removal rate can be maintained at about $20 \%$, while almost no treatment effect was obtained after $250 \mathrm{~h}$. Treatment effect of MCFA about COD was slightly inferior to CFA, the maximum removal rate was $30 \%$, the durability of MCFA was in line to the CFA.

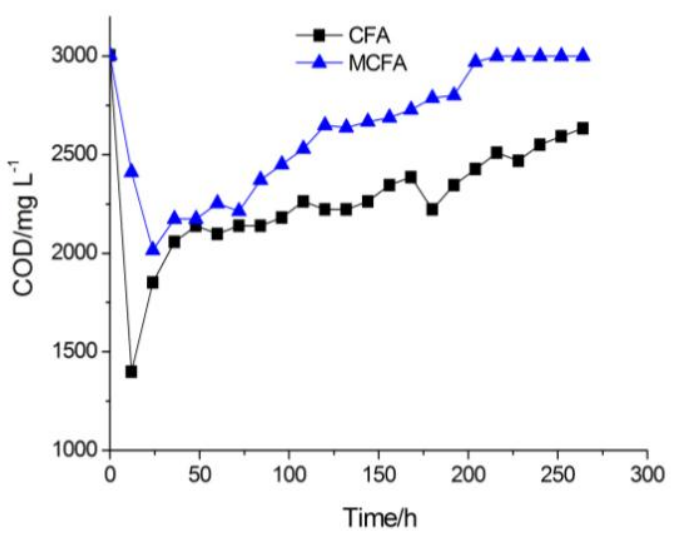

Figure 2. Treatment effect of COD

\section{Treatment Effect of $\mathrm{SO}_{4}^{2-}$}

As shown in Figure 2, the initial $\mathrm{SO}_{4}{ }^{2}$ - concentration was about $2750 \mathrm{mg} / \mathrm{L}$, the maximum removal rate of $\mathrm{SO}_{4}{ }^{2-}$ was about $60.4 \%$ and gradually weakened as the reaction time increased, when the reaction time was $250 \mathrm{~h}$ the $\mathrm{SO}_{4}{ }^{2-}$ 
removal rate can be maintained at about $28 \%$. Compared to CFA, treatment effect of MCF was not obvious, the maximum removal rate of $\mathrm{SO}_{4}{ }^{2-}$ was $36 \%$ when the reaction was $12 \mathrm{~h}$, and basically reached adsorption saturation after $120 \mathrm{~h}$.

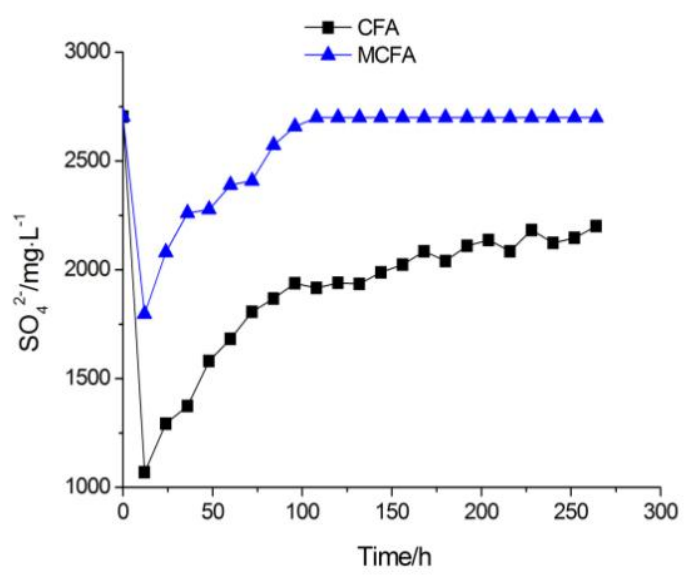

Figure 3. Treatment effect of $\mathrm{SO}_{4}{ }^{2-}$

D. Treatment Effect of Three Kinds of Heavy Metal Ions $\left(\mathrm{Cd}^{2+}, \mathrm{Cu}^{2+}\right.$ and $\left.\mathrm{Zn}^{2+}\right)$

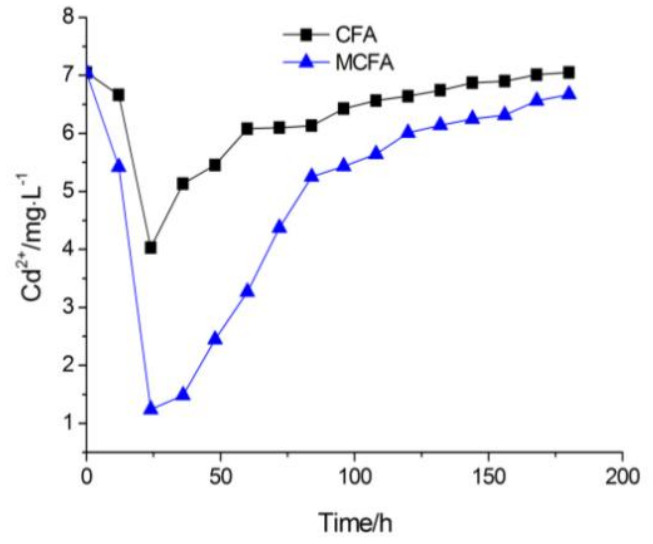

Figure 4. Treatment effect of $\mathrm{Cd}^{2+}$

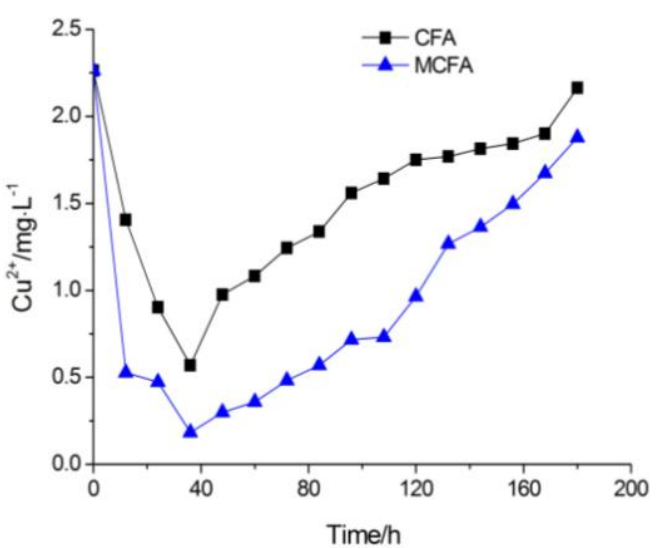

Figure 5. Treatment effect of $\mathrm{Cu}^{2+}$

As can be seen from Figure 4, Figure 5 and Figure 6,
Using CFA as the reaction medium of PRB have good removal effect of three kinds of heavy metal ions $\left(\mathrm{Cd}^{2+}, \mathrm{Cu}^{2+}\right.$ and $\mathrm{Zn}^{2+}$ ). The maximum removal of $\mathrm{Cd}^{2+}$ was $42.9 \%$ and soon reached adsorption saturation when reaction time was $120 \mathrm{~h}$. The treatment effect of $\mathrm{Cu}^{2+}$ was the best with the highest removal rate of $74.8 \%$, it has the longest durability and the removal rate of $\mathrm{Cu}^{2+}$ is still $40 \%$ after120 h. The removal rate of $\mathrm{Zn}^{2}+$ can reach $26.7 \%$ and gradually weakened as the reaction time increased.

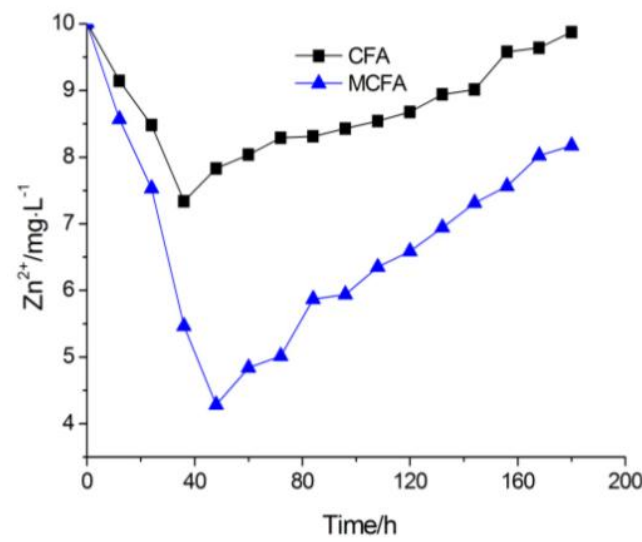

Figure 6. Treatment effect of $\mathrm{Zn}^{2+}$

Compared with CFA, MCFA showed better results. The treatment effect of heavy metal ions has greatly improved, the removal rate of $\mathrm{Cd}^{2+}$ and $\mathrm{Zn}^{2+}$ has more than doubled, the removal efficiency of $\mathrm{Cu}^{2+}$ also significantly improved. From Figure 4, it is clear that the removal rate of $\mathrm{Cd}^{2}$ ${ }^{+}$reached as high as $82.4 \%$ during the first $24 \mathrm{~h}$, the treatment effect is remarkable within 100 hours. As shown in Figure 5, it reach the highest removal rate of $91.85 \%$ for $\mathrm{Cu}^{2+}$ when reaction time was $36 \mathrm{~h}$ and a high removal rate is maintained between $36 \mathrm{~h}$ to $120 \mathrm{~h}$. Removal rate of $\mathrm{Zn}^{2+}$ increased from $26.6 \%$ to $57.2 \%$ and gradually weakened as the reaction time increased.

\section{CONCLUSIONS}

In this study, CFA and MCFA was investigated as a reaction medium of $\mathrm{PRB}$ for treatment of $\mathrm{AMD}$ at a starting $\mathrm{pH}$ of 4.0. Based on the experimental results, CFA showed a good adjustment effect for the $\mathrm{pH}$ of AMD, which enables the adjustment of $\mathrm{pH}$ from 4.0 to 7.0 or above, and can be maintained for a long time, it also have well removal effect of COD and $\mathrm{SO}_{4}{ }^{2-}$. Our experimental data reveal that MCFA have higher removal rate of heavy metal ions $\left(\mathrm{Cd}^{2+}, \mathrm{Cu}^{2+}\right.$ and $\mathrm{Zn}^{2+}$ ). MCFA shows promising potential for controlling AMD because of its low cost and high efficiency. High specific surface areas and small pore diameters are beneficial for pollutants removal efficiency. Modified CFA by acid method has simple process, and it can get good effect while have a low-cost, can also achieve the purpose of using waste treat waste which has a good application prospect. In the actual repair process, CFA can be combined with other reaction medium, or fixed high-degrading bacteria in the reaction material, made of bio-reactive material, and its removal effect will be greatly improved, 
what's more, it can extend the service life of materials. However, it will be necessary to design and execute some more detailed experiments to explore further application of CFA and other adsorbents for clean-up of the AMD, which can be treated at the mine to some degree, usually by neutralization at source by limestone, settling and tailings ponds or wetlands, although this process will not be ever fully efficient and accidents with the treatment system are inevitable.

\section{ACKNOWLEDGEMENTS}

Authors thank the financial supports from The National Natural Science Foundation of China (No.51274001) and State key laboratory of coal resources and safe mining (SKLCRSM10KFA05).

\section{REFERENCES}

[1] D. FENG, C. ALDRICH* and H. TAN, Treatment of acid mine water by use of heavy metal precipitation and ion exchange, Minerals Engineering.J.13(2000),623-625.

[2] D.H. Phillips, Permeable reactive barriers: A sustainable technology for cleaning contaminated groundwater in developing countries, Desalination. 248 (2009), 352-359.

[3] K.E. Roehl, K. Czurda, T. Meggyes, F. Simon and D.I. Stewart, Long-term Performance of Permeable Reactive Barriers, Elsevier, New York, 2005.

[4] S. Groudev, P. Geprgiev, I. Spasova, M. Nicolova, A.Angelov and L. Diels, Cleanup of acid mine drainage by means of a pilot-scale passive system, Annu. Univ. Min. Geol. 'St. Ivan Rilski' Part. 1. Geol. Geophys.48 (2005) 217-220.

[5] P. Beck, N. Harris and R. Sweeney, Design, Installation and Performance Assessment of a Zero Valent Iron Permeable Reactive Barrier in Monks town, Northern Ireland, CL:AIRE Technology Demonstration Report,TDP3, 2001, 120pp.
[6] V. Plagentz, M. Ebert and A. Dahmke, Remediation of ground water containing chlorinated and brominated hydrocarbons, benzene and chromate by sequential treatment using ZVI and GAC, Environ. Geol., 49(2006) 684-695.

[7] G.N. Manju, C. Raji and T.S. Anirudhan, Evaluation of coconut husk carbon for the removal of arsenic from water, Water Res., 32 (1998) 3062-3138.

[8] T.C. Hsu, C.C. Yu, C.M.Yeh, Adsorption of $\mathrm{Cu} 2+$ from water using raw and modified coal fly ashes, Fuel 87 (2008) 1355-1359.

[9] M.R. Jones, A. McCarthy, Utilising unprocessed low-lime coal fly ash in foamed concrete, Fuel 84 (2005) 1398-1409.

[10] M. Nisnevich, G. Sirotin, Y. Eshel, Lightweight concrete containing thermal power station and stone quarry waste, Mag. Concr. Res. 55 (2003) 313-320.

[11] J. Wang, X. Teng, H. Wang, H. Ban, Characterizing the metal adsorption capability of a class F coal fly ash, J. Environ. Sci. Technol. 38 (2004) 6710-6715.

[12] [12] H. Cho, D. Oh, K. Kim, A study on removal characteristics of heavy metals from aqueous solution by fly ash, J. Hazard. Mater. 127 (2005) 187-195.

[13] S.B. Wang, M. Soudi, L. Li, Z.H. Zhu, Coal ash conversion into effective adsorbents for removal of heavy metals and dyes from wastewater, J. Hazard. Mater. 133 (2006) 243-251.

[14] L. Tofan, C. Paduraru, D. Bilba, M. Rotariu, Thermal power plants ash as sorbent for the removal of $\mathrm{Cu}(\mathrm{II})$ and $\mathrm{Zn}(\mathrm{II})$ ions from wastewaters, J. Hazard. Mater.156 (2008) 1-8.

[15] B.H. Zhang, D.Y. Wu, C. Wang, S.B. He, Z.J. Zhang, H.N. Kong, Simultaneous removal of ammonium and phosphate by zeolite synthesized from coal fly ash as influenced by acid treatment, J. Environ. Sci. 19 (2007) 540-545.

[16] P. Pengthamkeerati, T. Satapanajaru, P. Chularuengoaksorn, Chemical modification of coal fly ash for the removal of phosphate from aqueous solution, Fuel87 (2008) 2469-2476.

[17] S.B. Wang, Q. Ma, Z.H. Zhu, Characteristics of coal fly ash and adsorption application, Fuel 87 (2008) 3469-3473. 